\title{
Molecular Docking and DFT Analysis of Methallyl Substituted N-Heterocyclic Carbene Salts for Potential Anticancer Activity \\ Elvan Üstün ${ }^{1}$ (D), Neslihan Şahin ${ }^{2}$
}

\author{
${ }^{1}$ Ordu University, Faculty of Art and Science, Department of Chemistry, Ordu \\ ${ }^{2}$ Cumhuriyet University, Faculty of Education, Department of Basic Education, Sivas
}

Geliş Tarihi / Received Date: 02.08.2021 Kabul Tarihi / Accepted Date: 13.09.2021

\begin{abstract}
The research recorded that growth hormones are effective in malignant cell formation and metastasis in many types of cancer. The releasing of vascular endothelial growth hormone has regulated by vascular endothelial growth hormone receptor. Therefore, inhibition of the vascular endothelial growth hormone receptor is important in hindering the formation of cancerous cells and metastasis. Many new molecules have been synthesized for fighting against cancer and their anticancer activity has been investigated. Since the first synthesis of $\mathrm{N}$-heterocyclic carbene molecules, many bioactivities research has been performed and some of them have become drug that used in treatment procedures. Due to the difficulty and cost of the methods used to examine the bioactivities of molecules, the foresight regarding the activities of possible active molecules is valuable. It is useful to make these preliminary evaluations in-silico methods. Comparing the results of the experimental analysis with the in-silico results is important in terms of having information about the validity of computational methods. In this study, N-heterocyclic carbene type benzimidazolium cations were analyzed with DFT/TDDFT computational methods and molecular docking for vascular endothelial growth factor receptor-2.
\end{abstract}

Keywords: N-heterocyclic carbenes, anti-cancer, molecular docking, DFT

\section{Antikanser Aktivite için Metallil Sübstitüe N-Heterosiklik Karben Tuzlarının Moleküler Doking ve DFT Analizi \\ Özet}

Çalışmalar büyüme hormonlarının, birçok kanser türündeki kötü huylu hücre oluşumunu ve metastazı etkilediğini göstermektedir. Vasküler endotelyal büyüme hormonunun salınımı, vasküler endotelyal büyüme hormonu reseptörü tarafından düzenlenir. Bu nedenle, vasküler endotelyal büyüme hormonu reseptörünün inhibisyonu, kanserli hücrelerin ve metastaz oluşumunun engellenmesinde önemlidir. Kansere karşı savaşmak için çok sayıda yeni molekül sentezlenmektedir ve bunların antikanser aktiviteleri araştırılmaktadır. Nheterosiklik karben moleküllerinin ilk sentezinden bu yana birçok biyoaktivite çalışması yapılmış ve bir kısmı tedavi prosedürlerinde kullanılan ilaç haline gelmiştir. Moleküllerin biyoaktivitelerini incelemek için kullanılan yöntemlerin zorluğu ve maliyeti nedeniyle, olası aktif moleküllerin aktivitelerine ilişkin öngörüler değerlidir. Bu ön değerlendirmeleri in-siliko yöntemlerle yapmakta fayda vardır. Deneysel analiz sonuçlarının in-silico sonuçlarla karşılaştırılması, hesaplama yöntemlerinin geçerliliği hakkında bilgi sahibi olmak açısından önemlidir. $\mathrm{Bu}$ çalışmada, N-heterosiklik karben tip benzimidazolyum katyonları, vasküler endotelyal büyüme faktörü reseptörü-2, DFT / TDDFT hesaplama yöntemleri ve moleküler doking ile analiz edildi.

Anahtar Kelimeler: N-heterosiklik Karbenler, anti-kanser, moleküler doking, DFT 


\section{Introduction}

Carbenes are neutral molecules containing a divalent carbon with a six-electron valence shell. These molecules, which are coordinatively unsaturated and unstable due to incomplete electron octet, are known as highly reactive intermediate forms in organic transformations such as cycloproponation (Jahnke \& Hahn, 2016). The first metal-carbene complex was synthesized by Wanzlick and Öfele in the following years (Öfele, 1968; Wanzlick \& Schönherr, 1968). After the synthesis of 1,3bis(adamantyl)imidazole-2-ylidene molecule, which was the first NHC, remarkable stability and relatively simple synthesis of this family take the attention of many scientists and became the subject of studies in a wide variety of studies (Arduengo et al., 1991). The well-known catalytic activity of NHC molecules must also be highlighted (Slimani et al., 2021). Many bioactivity properties of these molecules have been studied such as antibacterial, antioxidant and anti-cancer (Gürbüz et al., 2020; Haque et al., 2015). Also, the NHC-derived molecules currently used in various treatment procedures are considerable (Saijadi et al., 2019).

DFT has been very popular for calculating the solid-state structures since 1970 and provides useful information within the constraints of quantum chemical calculations (Kohn et al., 1996). Recently, the variety of basis sets and compatibility with experimental results has expanded the use of this method (Becke, 2014). The information obtained from the structural analysis provides useful information about reactivity. Frontier orbital analyzes are effectively used in qualitative analysis of active residues in electron exchange reactions and in relative quantitative analysis (Dewar, 1989). Moreover, with the Koopman Theory, the global reactivity descriptors obtained from the HOMO and LUMO orbital energies of the molecules allow investigations at a quantitative level (Jaque \& Toro-Labbé, 2002; Morell et al., 2005).

Molecular docking studies are considered an essential tool in-silico drug design study (De Ruyck et al., 2016). Molecular docking provides information about how two or more molecules interacts with each other. With a simple determination, docking is a molecular modeling technique that ensures predicting how a small molecule interacts with macromolecules such as protein (Ferreira et al., 2015; Sharif Siam et al., 2020). The supramolecular complexes formed by the interaction of a protein, enzyme, or nucleic acid with a small molecule play an important role in the analysis of protein dynamics (Sayın et al., 2015; Tezer \& Karakus, 2009).

Cancer is one of the most important diseases that cause death (https://www.who.int/healthtopics/cancer). Millions of people receive cancer treatment every year. The effectiveness and side effects of cancer drugs are the important problems of known treatment procedures (Suter, \& Ewer, 2013). For this reason, studies on new selective cancer drugs are continuing (Mayor, 2015). Due to the limited facilities, it is not possible to evaluate the cancer activities of all possible active molecules. One of the solutions to this problem is to analyze the active molecules in-silico methods.

The formation of new blood vessels from existed ones is called angiogenesis, which is essential in cell growth, tissue repair, wound healing (Carmeliet, 2003). Angiogenesis is associated with some diseases such as rheumatoid arthritis, diabetes, and cancer. The control of angiogenesis is directly related to the formation and growth of malign cells. Regulation of angiogenesis depends on growth factors such as Vascular Endothelial Growth Factors (VEGFs) (Bisht et al., 2010). One of the receptors of VEGF is Vascular Endothelial Growth Factor Receptor-2 (VEGFR-2). VEGFR-2 activation is effective in control of tumor growth and metastasis. Overexpression of VEGFR-2 has been recorded in breast, cervical, and non-small cell lung cancer. Therefore, in recent years, VEGFR-2 inhibitors have been developed (Karkkainen \& Petrova, 2000). Inconvenience of angiogenesis by inhibition of VEGFR-2 is used as a strategy for the design of selective cancer agents. Therefore, VEGFR-2 inhibition activity of a molecule can be considered as an indicator for its anticancer activity (Shah et al, 2021).

In this study, previously synthesized and characterized 1-methallyl-3-(2-chlorobenzyl) benzimidazolium chloride (1) and 1-methallyl-3-(2-methylbenzyl) benzimidazolium chloride (2) were optimized DFT/TDDFT methods (Figure 1) (Şahin et al., 2019). HOMO and LUMO regions of the 
molecules were determined. Also, global reactivity descriptors of the molecules were calculated with the energies of HOMO and LUMO. Finally, the interactions of the molecules with VEGFR-2 crystal structures were evaluated by the molecular docking method.

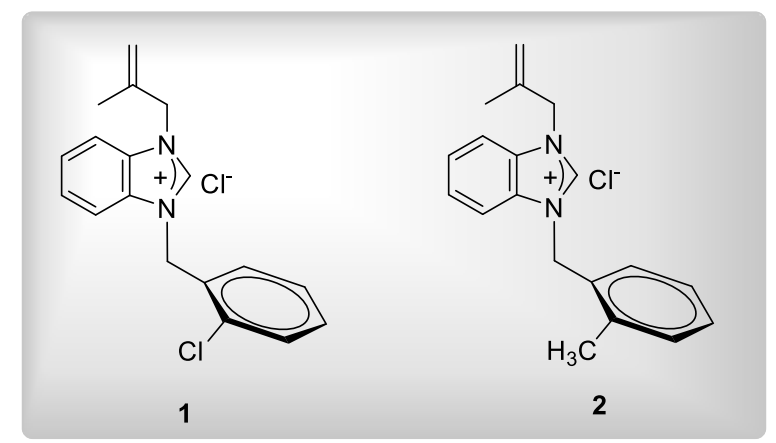

Figure 1. Methallyl Substituted N-heterocyclic Carbene Salts

\section{Material and Method}

B3LYP functional was used for DFT calculations with the resolution-of-the-identity (RI) approximation, the tightscf, a def2-TZVP/ def2-TZVP/J basis set and grid4 options by ORCA version 2.8 (Neese, 2012; Neese, 2009; Neese, 2006)). Global reactivity descriptors were also calculated by using HOMO and LUMO energies of optimized molecules (Choudhary et al., 2019; Vijayan et al., 2019).

AutoDock 4.2. with crystal structure of VEGFR-2 enzyme from RCSB protein data bank (PDB code: 1YWN) was used for molecular docking (https://www.rcsb.org/structure/1YWN) Water in the proteins was removed and Kollman charges and polar hydrogen atoms were evaluated for VEGFR-2 in the docking process. Gasteiger charges, randomized starting positions, optimizations, and torsions have been evaluated for molecules. The genetic algorithm population was used as 150 while applying Lamarkian genetic algorithms (Bikadi \& Hazai, 2009; Morris \& Lim-Wilby, 2008; Wei et al., 2002).

\section{Result and Discussion}

DFT-based calculation methods provide useful information about the structural properties of molecules. The energy and location of HOMO and LUMO orbitals of the molecules give useful information about the reactivity and active sites of the molecules in the reactions based on electron exchange. While the HOMO orbitals of the $\mathbf{1}$ and $\mathbf{2}$ are located on benzyl part of molecules, the LUMO orbitals are located on the benzimidazole regions. These results mean that while the molecules realize their electron-accepting through benzimidazole, they will donate electrons through benzyl (Figure 2).

According to the Koopman theory, the activity of the molecules can be predicted by using the energies of the HOMO and LUMO orbitals. Global reactivity descriptors included well-known quantities such as electron affinity, electronegativity, and ionization potential are criteria used to examine the reactivity of molecules. Moreover, chemical hardness, electrophilicity index, and chemical softness are developed as new criteria. Ionization potential, electron affinity, and electronegativity of $\mathbf{1}$ are higher than 2. The chemical hardness and softness values of both molecules can be examined in Table 1, and it is noted that $\mathbf{2}$ is softer. On the other hand, $\mathbf{1}$ has a higher electrophilicity index. It is concluded that $\mathbf{1}$ is more active than $\mathbf{2}$ with the global reactivity descriptors. 

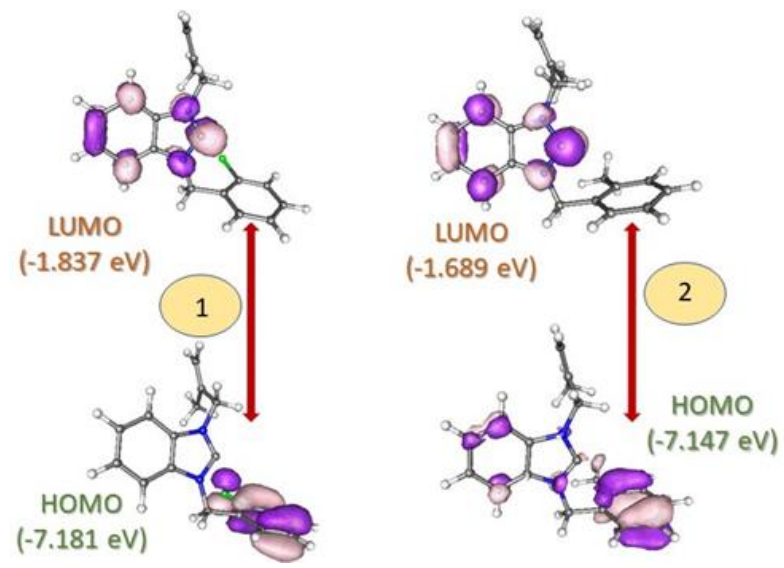

Figure 2. Graphical Illustrations and The Energies of HOMO and LUMO Orbitals of the Molecules

The molecular docking method has been frequently used in pharmaceutical chemistry research recently and is considered an essential tool. This method provides information about how small molecules interact with certain macromolecular structures. In this study, the anticancer activities of molecules that were analyzed previously with in-vitro cytotoxicity methods were compared with molecular docking results. In this study, interactions with VEGFR-2 molecule, which is known to be responsible for the formation, growth, and proliferation of cancerous cells, were investigated.

Table 1. The Calculated Quantum Chemical Parameters* for The Lower Energy Conformers each of 1 and 2 (in eV)

\begin{tabular}{lllllll}
\hline & $I P$ & $E A$ & $\chi$ & $\eta$ & $\delta$ & $\omega$ \\
\hline 1 & 7.181 & 1.837 & 4.509 & 2.672 & 0.187 & 3.802 \\
2 & 7.147 & 1.689 & 4.418 & 2.729 & 0.183 & 3.572
\end{tabular}

*IP: Ionization Potential (-Eномо); EA: Electron Affinity (-ELumo); $\chi$ : Electronegativity; $\eta$ : Chemical Softness; $\delta$ : Chemical Hardness; $\omega$ : Electrophilicity Index

Table 2. Molecular Docking Results of 1 and 2 for VEGFR-2 Target

\begin{tabular}{lll}
\hline Molecules & Bind. Aff.* $^{*}$ & Amino Acids Residue \\
\hline 1 & -6.79 & Cys1043, Asp1044, Glu883, Lys866, Leu887, Val897, Ile1042, Ile1023, \\
2 & $\begin{array}{l}\text { Arg1025, Cys1022, Leu1017, Val896, lle890, His1024, lle886 } \\
\text { Cys1043, Arg1025, Ile1023, His1024, lle1043, Val897, Leu887, Glu883, } \\
\text { Asp1044, lle890, Ile886, Val896, Leu1017, Cys1022 }\end{array}$
\end{tabular}

* Binding Affinity in $\mathrm{kcal} / \mathrm{mol}$.

The molecules interacted with the same region of VEGFR-2 included Cys1043, Asp1044, Val896, Cys1022 amino acids but the different interaction types and binding affinity were calculated (Table 2). The binding energy for 1 was calculated as $-6.79 \mathrm{kcal} / \mathrm{mol}$ and $-6.64 \mathrm{kcal} / \mathrm{mol}$ was calculated for 2 . Amide-pi interaction with Cys1043 and pi-anion interaction with Asp1044 contributed to the binding energy of 1. 2 realized the pi-cation interaction with Arg1025 and amide-pi interaction with Cys1043, pi-alkyl interactions with lle886, Val896, Leu1017, and Cys1022 were recorded (Figure 3). 


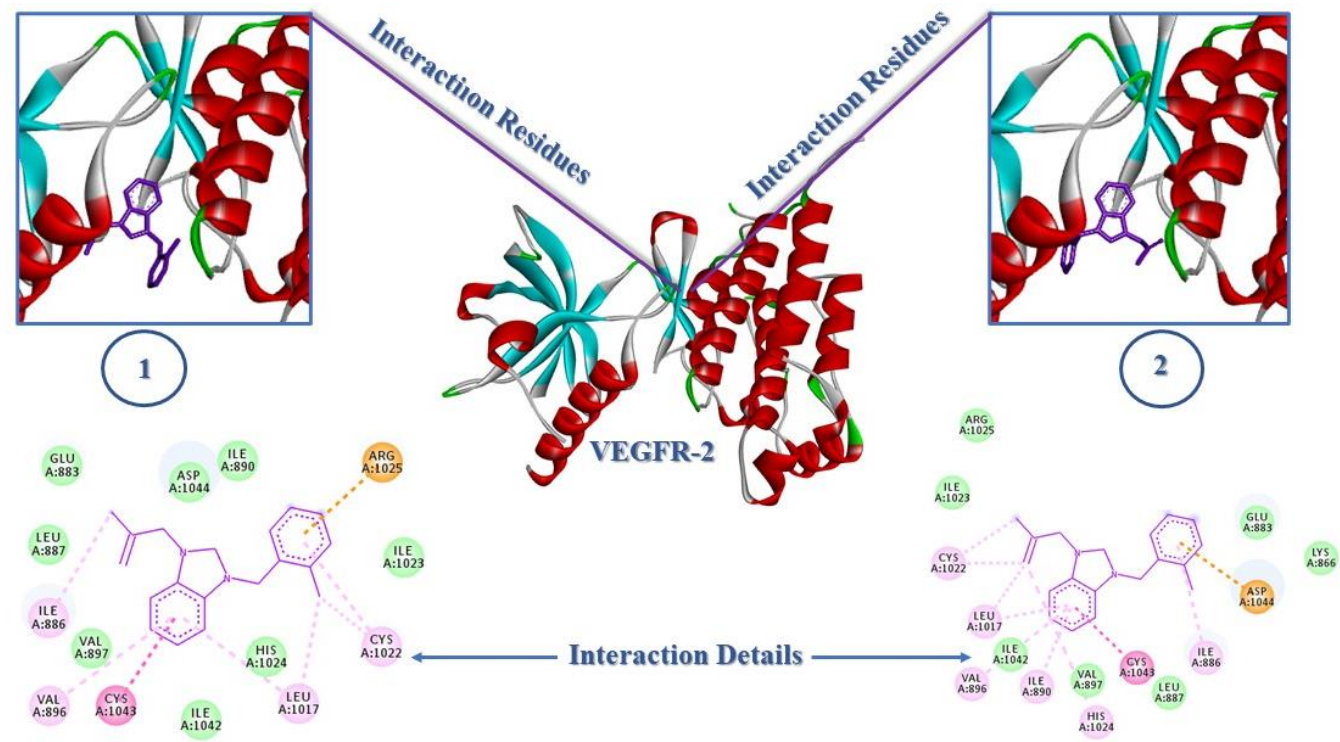

Figure 3. The Best Molecular Docking Pose of 1 and 2 with VEGFR-2 Crystal Structure

The cytotoxic activities of the molecules against MCF-7 and MDA-MB-231 breast cancer and DU-145 prostate cancer cells were investigated, and no activity was detected in 24-hour studies. In the 48-hour studies, only activity against prostate cancer was detected and the activity of $\mathbf{2}$ was higher than $\mathbf{1}$. While $\mathbf{2}$ showed higher activity in breast cancer, 1 presented higher activity in MDA-MB-231 and DU145. Although no major difference was noted with respect to molecular docking results, it is expected that 1 has stronger interactions and therefore will inhibit VEGFR-2 more effectively. As concluded, due to the VEGFR-2 inhibition results obtained in-silico, 1 could have better anticancer activity. These results agree with the experimental results obtained for MDA-MB-231 and DU-145.

\section{Authors' Contributions}

All authors contributed equally to the study.

\section{Statement of Research and Publication Ethics}

The author declares that this study complies with Research and Publication Ethics.

\section{Conflicts of Interest}

There is no conflict of interest between the authors.

\section{ORCID}

Elvan Üstün (iD https://orcid.org/0000-0002-0587-7261

Neslihan Şahin (D) https://orcid.org/0000-0003-1498-4170

\section{References}

Arduengo III, A. J., Harlow, R. L., \& Kline, M. (1991). A stable crystalline carbene [Erratum to document cited in CA114 (7): 62009r]. Journal of the American Chemical Society, 113(7), 2801-2801. https://doi.org/10.1021/ja00007a092

Becke, A. D. (2014). Perspective: Fifty years of density-functional theory in chemical physics. The Journal of Chemical Physics, 140(18), 18A301. https://doi.org/10.1063/1.4869598

Bikadi, Z., \& Hazai, E. (2009). Application of the PM6 semi-empirical method to modeling proteins enhances docking accuracy of AutoDock. Journal of Cheminformatics, 1(1), 1-16. https://doi.org/10.1186/1758-2946-1-15 
Bisht, M., Dhasmana, D. C., \& Bist, S. S. (2010). Angiogenesis: Future of pharmacological modulation. Indian Journal of Pharmacology, 42(1), 2. https://doi.org/10.4103/0253-7613.62395

Carmeliet, P. (2003). Angiogenesis in health and disease. Nature Medicine, 9(6), 653-660. https://doi.org/10.1038/nm0603-653

Choudhary, V., Bhatt, A., Dash, D., \& Sharma, N. (2019). DFT calculations on molecular structures, HOMO-LUMO study, reactivity descriptors and spectral analyses of newly synthesized diorganotin (IV) 2-chloridophenylacetohydroxamate complexes. Journal of Computational Chemistry, 40(27), 2354-2363. https://doi.org/10.1002/jcc.26012

De Ruyck, J., Brysbaert, G., Blossey, R., \& Lensink, M. F. (2016). Molecular docking as a popular tool in drug design, an in-silico travel. Advances And Applications in Bioinformatics and Chemistry: AABC, 9, 1. https://doi.org/10.2147/AABC.S105289

Dewar, M. J. (1989). A critique of frontier orbital theory. Journal of Molecular Structure: THEOCHEM, 200, 301-323. https://doi.org/10.1016/0166-1280(89)85062-6

Ferreira, L. G., Dos Santos, R. N., Oliva, G., \& Andricopulo, A. D. (2015). Molecular docking and structure-based drug design strategies. Molecules, 20(7), 13384-13421. https://doi.org/10.3390/molecules200713384

Gürbüz, N., Kaloğlu, N., Kızrak, Ü., Özdemir, I., Türkmen, N. B., Çiftçi, O., ... Naceur, H. (2020). Silver (I) $\mathrm{N}$-heterocyclic carbene complexes: Synthesis, characterization and cytotoxic properties. Journal of Organometallic Chemistry, 923, 121434. https://doi.org/10.1016/i.jorganchem.2020.121434

Haque, R. A., Choo, S. Y., Budagumpi, S., Iqbal, M. A., \& Abdullah, A. A. A. (2015). Silver (I) complexes of mono-and bidentate $\mathrm{N}$-heterocyclic carbene ligands: synthesis, crystal structures, and in vitro antibacterial and anticancer studies. European Journal of Medicinal Chemistry, 90, 82-92. https://doi.org/10.1016/j.ejmech.2014.11.005

Jahnke, M. C., \& Hahn, F. E. (2016). Introduction to N-heterocyclic carbenes: Synthesis and stereoelectronic parameters. In Silvia Diez-Gonzalez (ed.), Laboratory Curiosities to Efficient Synthetic Tools (pp. 1-45). https://doi.org/10.1039/9781782626817-00001

Jaque, P., \& Toro-Labbé, A. (2002). Characterization of copper clusters through the use of density functional theory reactivity descriptors. The Journal of Chemical Physics, 117(7), 3208-3218. https://doi.org/10.1063/1.1493178

Karkkainen, M. J., \& Petrova, T. V. (2000). Vascular endothelial growth factor receptors in the regulation of angiogenesis and lymphangiogenesis. Oncogene, 19(49), 5598-5605. https://doi.org/10.1038/si.onc.1203855

Kohn, W., Becke, A. D., \& Parr, R. G. (1996). Density functional theory of electronic structure. The Journal of Physical Chemistry, 100(31), 12974-12980. https://doi.org/10.1021/ip960669|

Mayor, S. (2015). Side-effects of cancer drugs are under-reported in trials. The Lancet Oncology, 16(3), 107. https://doi.org/10.1016/S1470-2045(15)70023-9

Morell, C., Grand, A., \& Toro-Labbe, A. (2005). New dual descriptor for chemical reactivity. The Journal of Physical Chemistry A, 109(1), 205-212. https://doi.org/10.1021/ip046577a

Morris, G. M., \& Lim-Wilby, M. (2008). Molecular docking. In Molecular modeling of proteins (pp. 365382). Humana Press. https://doi.org/10.1007/978-1-59745-177-2 19

Neese, F. (2006). A critical evaluation of DFT, including time-dependent DFT, applied to bioinorganic chemistry. JBIC Journal of Biological Inorganic Chemistry, 11(6), 702-711. https://doi.org/10.1007/s00775-006-0138-1 
Neese, F. (2009). Prediction of molecular properties and molecular spectroscopy with density functional theory: From fundamental theory to exchange-coupling. Coordination Chemistry Reviews, 253(5-6), 526-563. https://doi.org/10.1016/j.ccr.2008.05.014

Neese, F. (2012). The ORCA program system. WIREs Comput Mol Sci, 2, 73-78. https://doi.org/10.1002/wcms.81

Öfele, K. (1968). 1, 3-Dimethyl-4-imidazolinyliden-(2)-pentacarbonylchrom ein neuer Übergangsmetall-carben-komplex. Journal of Organometallic Chemistry, 12(3), 42-43.

Şahin, N., Şahin-Bölükbaşı, S., \& Marşan, H. (2019). Synthesis and antitumor activity of new silver (I)$\mathrm{N}$-heterocyclic carbene complexes. Journal of Coordination Chemistry, 72(22-24), 3602-3613. https://doi.org/10.1080/00958972.2019.1697808

Sajjadi, M., Nasrollahzadeh, M., \& Tahsili, M. R. (2019). Catalytic and antimicrobial activities of magnetic nanoparticles supported $\mathrm{N}$-heterocyclic palladium (II) complex: A magnetically recyclable catalyst for the treatment of environmental contaminants in aqueous media. $\begin{array}{lllll}\text { Separation and Purification Technology, 227, } & 115716 .\end{array}$ https://doi.org/10.1016/j.seppur.2019.115716

Sayin, K., Karakaş, D., Karakuş, N., Sayin, T. A., Zaim, Z., \& Kariper, S. E. (2015). Spectroscopic investigation, FMOs and NLO analyses of $\mathrm{Zn}$ (II) and Ni (II) phenanthroline complexes: A DFT approach. Polyhedron, 90, 139-146. https://doi.org/10.1016/i.poly.2015.01.047

Shah, A. A., Kamal, M. A., \& Akhtar, S. (2021). Tumor angiogenesis and VEGFR-2: Mechanism, pathways and current biological therapeutic interventions. Current Drug Metabolism, 22(1), 50-59. https://doi.org/10.2174/1389200221666201019143252

Sharif Siam, M. K., Sarker, A., \& Sayeem, M. M. S. (2020). In silico drug design and molecular docking studies targeting Akt1 (RAC-alpha serine/threonine-protein kinase) and Akt2 (RAC-beta serine/threonine-protein kinase) proteins and investigation of CYP (cytochrome P450) inhibitors against MAOB (monoamine oxidase B) for OSCC (oral squamous cell carcinoma) treatment. $\begin{array}{lllll}\text { Journal of Biomolecular Structure and } & \text { 13. }\end{array}$ https://doi.org/10.1080/07391102.2020.1802335

Slimani, I., Mansour, L., Özdemir, I., Gürbüz, N., \& Hamdi, N. (2021). Synthesis, characterization and catalytic activity of PEPPSI-type palladium-NHC complexes. Inorganica Chimica Acta, 515, 120043. https://doi.org/10.1016/i.ica.2020.120043

Suter, T. M., \& Ewer, M. S. (2013). Cancer drugs and the heart: importance and management. European Heart Journal, 34(15), 1102-1111. https://doi.org/10.1093/eurhearti/ehs181

Tezer, N., \& Karakus, N. (2009). Theoretical study on the ground state intramolecular proton transfer (IPT) and solvation effect in two Schiff bases formed by 2-aminopyridine with 2-hydroxy-1naphthaldehyde and 2-hydroxy salicylaldehyde. Journal of Molecular Modeling, 15(3), 223-232. https://doi.org/10.1007/s00894-008-0397-6

Vijayan, V., Purushothaman, E., Arjunan, V., \& Mohan, S. (2019). Quantum Chemical Investigations on the Structure, Bonding Orbitals, Frontier Molecular Orbitals and Reactivity Properties of Diphenylguanidine-Vulcanizing Accelerator. Chemical Science, 8(3), 318-330. https://doi.org/10.7598/cst2019.1575

Wanzlick, H. W., \& Schönherr, H. J. (1968). Direct synthesis of a mercury salt-carbene complex. Angewandte Chemie International Edition in English, 7(2), 141-142.

Wei, B. Q., Baase, W. A., Weaver, L. H., Matthews, B. W., \& Shoichet, B. K. (2002). A model binding site for testing scoring functions in molecular docking. Journal of Molecular Biology, 322(2), 339-355. https://doi.org/10.1016/S0022-2836(02)00777-5 